UDC 159.937:128:364.2(0.45)

DOI: $10.52534 / \mathrm{msu}-$ pp.7(4).2021.86-95

\author{
Liudmyla V. Piankivska ${ }^{\star}$, Tetiana B. Kodlubovska ${ }^{2}$ \\ ${ }^{1}$ State Research Institute of the Ministry of Internal Affairs of Ukraine \\ 01011, 4a Ye. Hutsalo Ln, Kyiv, Ukraine \\ ${ }^{2}$ Shupyk National Healthcare University of Ukraine \\ 04112, 9 Dorohozhytska Str., Kyiv, Ukraine
}

\title{
Features of Perception of Death by a Seriously III Child
}

\section{Article's History: \\ Received: 15.08.2021 \\ Revised: 16.09 .2021 \\ Accepted: 20.10.2021}

\section{Suggested Citation:}

Piankivska, L.V., \& Kodlubovska, T.V. (2021). Features of perception of death by a seriously ill child. Scientific Bulletin of Mukachevo State University. Series "Pedagogy and Psychology", 7(4), 86-95.

\begin{abstract}
The relevance of the study is conditioned upon insufficient coverage of the issue of experiencing and awareness of death by seriously ill children. The studied problems generally concern basic existential issues of the child's personality and parents and require certain developments regarding the specific features of communicating disappointing news to the child, talking to him about death and directly perceiving this fact, and a certain construction of family relations. The purpose of the article is to study the specific features of perception of death by a seriously ill child. To achieve this goal, the authors rely on the methodology of a systematic approach and use a set of scientific methods, including analysis, synthesis, interrelation, comparison, including systematisation and generalisation. It is established that the perception of death by a seriously ill child depends on age characteristics, the end stage of development of the disease, the level of intellectual development, and their own experience. Scientific sources are analysed and age-related features of the perception of death by a seriously ill child are demonstrated. Psychological components of awareness and understanding of the fact of the death by a child at the end stage of the development of the disease are identified, considering his age. The article describes the specific features of attitudes to the death of seriously ill children at the cognitive, emotional and behavioural levels. It is demonstrated that information about the approach of death can lead to changes in fundamental ideas about the constancy and safety of a child's life. Prospects for further research are focused on developing methodological recommendations for parents and doctors to support a seriously ill child, considering his "view of the world", personality in order to saturate life with positive moments
\end{abstract}

Keywords: sphases of death perception, age features, emotional state, behavioural and cognitive aspect, fear, anxiety, post-traumatic stress disorder

\section{INTRODUCTION}

Life and death are traditional philosophical categories. Death is a difficult concept to understand because it includes a number of psychological, biological, socio-cultural and religious components. In religion, it has always been perceived not as the end, but as a path to transition to eternity. During a terminal illness, approaching death becomes an expected reality. Its presence radically transforms all aspects of being and the quality of life in general. In the first place comes the problem - the meaning of suffering. So, turning to the question of perception of death, J. Emery, in his thorough work on palliative care for children, focuses on the fact that in regions where child mortality is high, people have developed "immunity" and do not treat this problem really empathically, and where it is rare-adults have correspondingly little experience of communicating on the issue under study and show fear of death [1].

In many foreign countries, the specific features of reporting disappointing news to a child depend on cultural, religious characteristics and traditions. In the United States of America, previously complex diagnoses were hidden from the family and the question of the possible choice of the treatment itself was not discussed. Over the 
past thirty years, approaches to this issue have changed. American doctors openly provide information to parents about the child's condition and almost always report the diagnosis to the children themselves [2]. In Japan, paediatricians traditionally avoid directly discussing the specifics of treatment with both children and their parents, so as not to break faith in the success of treatment and maintain the child's inner resilience and courage [3].

In Ukrainian culture, the issue of death, especially of a child, is quite painful and limited for discussion. In general, parents believe that young children "have not grown up" to understand the phenomenon of death. Various observations and results of research show exactly the opposite. In particular, young children have a well-formed idea of death, which is supplemented and expanded with their development [4;5]. Children who have experienced loss between the ages of three and six show a deeper understanding of death [6]. Cancer-stricken young patients experience death from the perspective of total pain/suffering [7]. Some children at the end stage of the disease feel that they are dying, even before they are informed about it, and very young children easily talk about it. For adults (parents, doctors), the most complicated issue is how to openly tell a child about his difficult diagnosis, incurable illness, or death. Family members motivated by the fear of loss and the desire to "not harm" the child's psyche, try to protect it from reality, avoid discussing this aspect in every possible way, which leads to a loss of trust in the child's parents, loneliness, increased deep fears, and can also provoke its acute traumatisation. It is worth noting that for a seriously ill child, burdensome changes at the functional, personal, socio-psychological levels are real. In the process of rehabilitation of children at the end stage of the disease, in general, all work is focused on the treatment process and it is the psychological properties of the individual that are not sufficiently considered, which can contribute to the deterioration of health.

The studied problem becomes relevant and puts forward a number of primary existential questions, the answers to which are rooted in the psychological, medical, and philosophical spheres. In the scientific literature, the issues of children's experience and awareness of death are not sufficiently covered, since adults themselves are afraid of the problem of human transition, in the face of the sacred moment of death. There is also a lack of certain developments regarding the specific features of communicating disappointing news to a child, talking about death, its attitude to death, and the necessary methodological recommendations for parents to adapt them to the process of a child's death. This indicates the need to study the specific features of perception of death by a seriously ill child in the context of a terminal illness and develop a system of socio-psychological support for seriously ill children.

The purpose of the article lies in studying the specific features of the perception of death by a seriously ill child.

\section{LITERATURE REVIEW}

Analysis of recent studies and publications shows that the problem of the peculiarities of perception of death by a seriously ill child attracts the attention of doctors, psychologists, psychotherapists, teachers, social service specialists, etc. A significant contribution to the development of theory and practice on this topic was made by foreign scientists: D. Berman [8], J. Binnebezel [7], A. Gesell [8], I. Orbach, Y. Gross, and H. Glaubman [9], F. Ilg [8], N. Klipinina [2] and others. Given the complexity of the problem, research and works on this topic are already appearing in Ukrainian psychological science. In particular, it is considered by V. Zlyvkov, and S. Lukomska [10], H. Katolyk [4], O. Riha and A. Penkov [11], M. Stulkovskaya [4].

A number of researchers prove that children's awareness of this event occurs through biological cognition, which is subsequently overlaid with spiritual elements that cause a difficult understanding of the biological reality of death [12]. Individual reactions of a child to the inevitability of transition primarily depend on the nature of his disease, its dynamics and psychological characteristics. In some cases, children expect death as salvation explained by the duration of the disease and pain intolerance.

The traditional concept of death perception is considered through the prism of a number of components: irreversibility/constancy (death is perceived as a permanent and irreversible state); inevitability/universality (all living things must die); application (awareness that only living beings die); termination (awareness of the cessation of bodily processes in the body after death); causality (understanding that death is a consequence of violations of body functions) [13]. V. Oaklander points out that Lenore Terr in his work "I'm too afraid to cry" describes the dynamics of children's grief through the phases of denial, protest, despair and problem solving [14]. The author of the concept of psychological assistance to patients at death, E. Kubler-Ross, identified five phases of acceptance of death, which can occur arbitrarily or selectively in a seriously ill person [15]:

- denial (first-heard information about an incurable disease is often not initially recognised, denied, or accepted by a person);

- protest (the patient tries to find a cause-and-effect relationship with the disease and, without a rational explanation, begins to resent, blame doctors, close people);

- "bargaining" (the patient tries to act in a compromise way: he seeks to change his own life, hoping for the best, give up bad habits, improve. These experiences are changeable and often accompanied by both redemption and the search for effective solutions);

- depression (the patient retires, his activity decreases, despair, uncertainty in the future appears, interest in lifeis lost);

- acceptance of death (the patient begins to realise and accept death).

It can be stated that children who are informed about the fact of death go through the same stages of its 
acceptance as adults. At the same time, their period of acute grief is usually shorter. Very young children experience painful feelings of discomfort, but not shock, because they generally do not understand what happened, at the same time feel and react to the family atmosphere and features of interpersonal relationships. Depending on the age characteristics, the terminal stage of development of the disease, the level of intellectual development, and their own experience, these phases of death perception can manifest themselves differently in seriously ill children. The announcement of the diagnosis to them causes the same reactions as the news of death, which are transformed over time and manifest themselves in certain emotional reactions [16].

The article reproduces an attempt to analyse the features of the child's ideas about death at the end stage of the disease development, described in scientific sources, based on research interest in accordance with the chosen topic.

\section{MATERIALS AND METHODS}

The problem of changes in the child's personality under the condition of an established diagnosis of an incurable disease is both a complex two-way aspect of psychological research both in the context of experiencing loss and a component of the psychology of child personality development. These components determined the specific features of choosing the methodological foundations of research.

In accordance with the complex nature of the topic of the article and to better understand and deepen all the key aspects of the problem, a set of such scientific theoretical methods was applied in the work: analysis and synthesis, comparison, interrelation, systematisation and generalisation of scientific sources. Using the analysis method, scientific sources of foreign and Ukrainian scientists and practitioners were studied to identify the psychological features of the perception of death by a seriously ill child and justify the significance of the problem in modern conditions for doctors, parents, and teachers. The applied synthesis method contributed to the study of such psychological aspects of awareness of death by a child at the end stage of the disease development as emotional, behavioural and cognitive components of understanding the event, as a result of which the main views on the chosen topic were outlined. Important for achieving the results of the study was the use of the comparison method, which allowed comparing the scientific views of researchers regarding the specific features of perception of death by a seriously ill child at different age stages of its development. Thanks to the generalisation method, causal relationships are established and the basic features of the child's perception of death are determined.

The methodological basis of the research consists of scientific publications on medical, age, crisis psychology, and palliative and hospice medicine. The methodological basis of the work is the concept of E. Kubler-Ross on providing psychological assistance to patients at death and the theory of I. Binnebezel on the specific features of experiencing death in children at the end stage of the disease $[7 ; 15]$. The applied research methods contributed to a consistent and clearly structured presentation of the material, helped to comprehensively and systematically demonstrate the results of a theoretical study on the key characteristics of a child's perception of death. They also allowed conducting a comprehensive and in-depth study on the selected issues. In general, the presented study was conducted considering the principles of a systematic approach (integrity, hierarchy of construction, structuring, multiplicity) and provided for a comprehensive study of theoretical constructs.

Based on a certain methodological basis, the study of the specific features of perception of death by a seriously ill child was conducted in several stages. At the first stage, scientific and psychological sources over the past five years were processed to confirm the relevance of the chosen topic and determine the purpose of the study. At the second stage, Ukrainian and foreign scientific publications on the age-related features of the perception of death by a seriously ill child were analysed. The main focus is on the interpretation of children's ideas about death. At this stage, the specific features of attitudes to the death of seriously ill children at the cognitive, emotional and behavioural levels were studied and key characteristics were systematised in accordance with their age development. The article also described changes in fundamental ideas about the constancy and safety of a child's life at the end stage of the disease and focused on rethinking the importance of life and mobilising internal resources. At the third stage, the results of the study were summarised and conclusions were drawn. The results obtained helped to outline the prospects for further research.

\section{RESULTS AND DISCUSSION}

\section{Age-related features of death perception by a seriously ill child}

Any person always has a premonition, knows the inevitability of their own death, the approach of which is accompanied by a complex of psychological changes that have their own characteristics at the terminal stage. Children, having a variety of plans for the future, most often live the entire spectrum of intense individual internal experiences in the realities of the inevitability of transition due to illness. In the future, this crisis situation can lead to changes through reconciliation with the inevitability and avoidance of any actions to combat the disease, complete indifference and isolation from the social environment, or through the mobilisation of internal forces for struggle and self-development.

The analysis of scientific sources indicates a variety of visions of scientists and practitioners on the outlined topic, each of which reveals a number of specific problematic aspects. In general, the development of a child's idea of death occurs along with its growth: from birth to adolescence. A. Penkov and O. Riha in their "Handbook for 
parents of children with incurable diseases" focus on the fact that the child is a unique and independent person who has his own thoughts and judgments and has his own understanding of death, which depends on age changes and is determined by the level of his development, culture, close environment, religious confessions and his own life experience [11]. Researcher B. Kane points out that children who have experienced death-related events between the ages of three and six have a deeper understanding of death, and this exceeds the generally accepted ideas about the phenomenon in accordance with age-related cognitive development [6]. In the article "Children's ideas about death" Stanford Children's Health it is noted that each child has an individual idea of death, the formation of which is most influenced by past experience, age characteristics, emotional development and close environment. Also, modern cartoons, games, and books carry information about death. They influence the perception of death by a child and the feelings of adults, and their fear of death is often transmitted to children [17]. According to the results of the research, I. Orbach, Y. Gross, H. Glaubman and D. Berman state that the age, anxiety and cognitive abilities of children affect their general ideas about the death of animals and humans [9]. Understanding and perception of death by a child is formed based on their own experience according to the theory of J. Binnebezel: through cycles of sleep and wakefulness, separation from parents and existing fears, which can be enhanced by observing animals [7].

Let's take a closer look at age-related features of perception of death by a seriously ill child. Scientists G. Panagiotaki, G. Nobes, A. Ashraf, and H. Aubby note that at the age of three, children understand the irreversibility of death, and the child begins to realise the causal relationship by the age of eight [18]. Foreign researchers state that seven-or eight-year-olds begin to understand the definitive nature, irreversibility, and universality of the fact of death. There is an awareness of the causality of the phenomenon by children of ten to eleven years of age, which depends on their intellectual level of development [9]. The well-known fairytale therapist R. Tkach, referring to German researchers G. Brown and G. Polmeier, points out that children under the age of five have not yet developed a stable attitude to the irreversibility of death. In their understanding, to die is to continue to exist in another form of being. At the age of five, the child has an idea of separation, but he reacts to death with fear and internal protest. At the same time, there are cases when they show curiosity. In general, they perceive the fact of death as a dream and begin to realise that it differs from real life $[19 ; 20]$. Children of primary school age interpret death as a punishment for evil or as a natural end to life. Older preschool children have a clear idea of death. They often personalise it. The older preschooler already has a fairly clear idea of death $[19 ; 20]$. Ukrainian psychologists V. Zlyvkov, S. Lukomska also demonstrate that children perceive death differently: up to five years they understand it as a temporary phenomenon or a dream; from six to nine years they realise it as irreversible and do not perceive it as inevitable; from nine years and older they see both in it [10]. In this context, it is worth paying attention to the research of foreign researchers O. Gesell, F. Ilg, L. Ames [8]. They identify genetically determined stages in the development of a child's perception of death in the process of its development. Scientists state that at the age of one to three years, they have an unformed idea of death. At the age of four, information about death does not cause any emotional reaction in the child, but at the same time, it connects it with pain and sadness. At the age of five, the child is able to recognise the immobilized body and the irreversibility of the event. At the age of six, they begin to show emotions about the fact of death, curiosity about its causes and the rite of burial, and concern about the likely death of family members, especially their mother. At the same time, it does not correlate this with its own probability of death. At the age of seven, they have a greater interest in the reasons for this fact and funeral rites. At the age of eight, they begin to think about what will happen after death and to realise the inevitability of what happened. From the age of nine, the fear of death decreases with the awareness of its irreversibility. At the age of ten, they realistically perceive the fact itself and are not interested in its biological component [8].

Modern explanation of the vision of children's perception of death, presented in the article "Children's perception of death", is of particular interest [17]. It states that infants generally have no understanding of death. They only respond to separation from their parents, certain treatment procedures at the end stage of the disease, and changes in their usual daily routine [17]. Preschoolers may already be aware of the fear of adult death. They perceive it as a temporary event through fantastic stories from cartoons. Children of this age do not understand the constancy and irreversibility of the fact. Their loved ones have a significant influence on their perception of death. These children may ask questions about the fact and have feelings of guilt and shame. Seriously ill preschoolers may think that death is a punishment for their actions and do not understand why their parents could not protect them from the disease. The article notes that children of primary school age have more realistic ideas about death. They are able to perceive it and recognise the fact of irreversibility. They have an interest in the physical process of death and the events that follow. Children may have fears of their own death conditioned upon ignorance of what will happen to them later. It is this fact and separation from family members that are the main causes of fear of death of a child of primary school age [17]. It also describes the perception of death by adolescents. They are strongly influenced by the idea of death. Most of these children understand its irreversibility for everyone. If they are aware of their own fact of death, they can ask for religious or cultural rituals to be observed during burial. The main topic for them conditioned upon age characteristics is the feeling of immortality or liberation from it. For them, their own self-esteem becomes important [17]. So, we 
see that there is some discrepancy in the views of researchers regarding the perception of death by a child at a certain age, including a seriously ill one. Their awareness of death, in general, is formed under the influence of their own experience and individual development, culture and religious confessions of their inner circle.

\section{Characteristics of attitudes to the death of seriously ill children at the cognitive, emotional and behavioral levels}

Let's try it outline features of attitudes to the death of seriously ill children at the cognitive, emotional and behavioral levels. Mexican scientists prove that cultural customs influence the development of cognitive and affective processes in children that are associated with death [21]. Ukrainian researchers $M$. Tomchuk, $M$. Yatsiuk focus on the fact that a child, in the event of a collision with a situation that he is not able to realise by the level of their own development, gets into emotionally difficult circumstances and faces a number of personal and social risks [22]. Notably, the announcement of the diagnosis to the child causes a similar reaction to the announcement of death and is manifested by shock, numbness, distrust and denial. Over time, they develop emotions of fear, anxiety, feelings of helplessness and anger ("why exactly did this happen to me?"). The message received may also cause feelings of resentment towards healthy people and children. Scientist P. Nykonenko, based on the research of T. Merilova, states that in the process of treatment, a patient with cancer shows suffering and various fears, especially loneliness and death, and before illness, pain, novelty and possible changes [23]. I. Binnebezel also points out the manifestations of fear of loneliness in the stories of seriously ill children [7, p. 298].

A number of foreign and Ukrainian researchers prove that the main cause of children's suffering is the fear of pain $[4 ; 7-9]$. It is established that during a single hospitalisation, the highest indicator of spiritual suffering and fear of pain is observed in children with cancer [4, p. 213-214]. Children at the end stage of the disease develop special ideas, accompanied by the emotion of fear and their own fantasies about the features of treatment and dynamics of the disease $[4 ; 7]$. Their emotions are most often reinforced by a lack of love and understanding from their loved ones. It should be stated that such cancer-stricken adolescents may show a tendency to suicide. Notably, prolonged illness causes traumatic emotional experiences in the child and depletion of the body's adaptive reserves, which as a result lead to the appearance of apathy and indifference in him. The prolonged stay of a seriously ill child in this state affects the reduction of needs, simplification of a number of emotions, the emergence of obsessive thoughts, and also leads to levelling of interests, disappointment in life, immersion in their own world of experiences, avoiding social connections. J. Binnebezel and H. Katolyk in their work "Palliative and hospice care: extra-medical multidimensional aspects" state that cancer-stricken children experiencing daily deaths of hospitalised children are characterised by four elements of total pain, among which are: emotional experiences, social suffering and less significant are physical pain and spiritual suffering [7, p. 292]. The authors prove that in terminally $i$ 11 children, emotional and spiritual suffering are intertwined and difficult to separate. In these patients, during the "interaction" with an incurable disease, the existence of a relationship with death arises, which is caused by the fear of death and the thirst for immortality, and directly affects the reorientation of the worldview to spirituality "from suffering to immortality". The researchers note that social suffering in these children explained by value and interpersonal changes manifests itself in the family, social and hospital spheres. Spiritual and social suffering in the subjects are also interrelated in the context of relation to death [4, p. 214 ; 7]. O. Bayer points out that parents' anxiety is transmitted to the child, especially to adolescents, conditioned upon their avoidance of reporting the established diagnosis. This fact also affects the violation of interpersonal relationships and emotional climate in the family [16]. Open conversations about death encourage preschoolers to make more positive assessments, do not cause sadness, but contribute to the expression of existing feelings [24]. That is, it is the close environment (parents, brothers, sisters, friends) of a seriously ill child that acts as certain energy, psychological, and spiritual buffer that helps him overcome the existing chaos of difficult internal experiences. However, this process can also generate the opposite side of the situation - a sick child demonstrating his own courage, faith in recovery initiates and transforms "life on a par with death". There is a certain symbiosis of joint living of being and transition through awareness, expanding the boundaries of eternal questions. A. Bayer also notes that long-term illness conditioned upon existing mental deprivation affects the development of personality and can lead to the appearance of symptoms of post-traumatic stress disorder (PTSD). A seriously ill child has recurring dreams and worries due to the influx of heavy memories of the disease, increased sensitivity to external influences, impulsivity, conflict and misunderstandings with peers [16].

The emotions of seriously ill people are often filled with sadness, grief, and fear. In older children, sadness is accompanied by pleasant memories of the past and uncertainty about their own future. The emotion of grief causes self-pity contributes to the emergence of feelings of loneliness, and also, as a result, affects the separation of life before and after illness. A child's mental development affects the depth, duration, and immersion in feelings of grief. Researcher O. Aleksandrova focuses on the fact that a sick child, keeping his own experiences "in himself”, becomes more depressed, withdrawn and this affects his physical state of health [25]. In adolescents, the fact that they realise their own death can lead to frustration explained by the inability to achieve their goals and lead to personal changes. They may have feelings of loneliness, anger, and fear that arise during treatment [17]. The famous scientist psychologist I. Yalom in his work "Existential psychotherapy" 
demonstrates the protective mechanisms used by children of different ages to control their own anxiety caused by the fear of death: denial of death, which is a temporary state or sleep; belief in the invulnerability of the "I"; belief in a saviour who can restore the child's life; denial of death in children and personification of death [26]. So, based on the results of research of scientific works, it can be concluded that in seriously ill children, understanding of death is expressed by a number of emotional, cognitive and behavioural manifestations. They also have symptoms of post-traumatic stress disorder and mechanisms of psychological protection.

\section{Key emotional, cognitive and behavioural aspects of the perception of death by seriously ill children that are characteristic of a certain age period}

Let's try to describe the emotional, cognitive, and behavioural aspects in more detail perception of death seriously ill children, considering their age characteristics. The authors of the article "Children's idea of death" indicate that infants who begin to walk are able to feel the emotions of the environment (anxiety, fear), which have a depressed mood, manifestations of sadness, anger [17]. Researcher O. Aleksandrova also notes that children aged six to eighteen months are able to show sadness and melancholy. They are aware of the fact itself as a temporary absence or separation and are able to respond to the mood and emotions of parents associated with the state of health of a seriously ill child. In general, their behaviour is characterised by unwillingness to remain without their parents and their attention, expressed by crying, manifestations of aggression against those people who are close to them. These children strive for comfort and comfortable living conditions [25]. The emotional state of children aged eighteen months to five years is characterised by confusion and guilt and dependsentirely on the attitude of parents to the situation with their state of Health. The child's awareness of the fact of transition can manifest itself in his fear of his own state of health and safety. Seriously ill children of this age are characterised by egocentricity, faith in their own "magical" thoughts, which, in their opinion, can change the "course" of events [25]. The researcher states that preschoolers aged four to five years consider themselves strong, but show fear, feelings of weakness and helplessness, which they compensate for with their own fantasies. Their behaviour is characterised by isolation, demanding of others, some irritability, and sleep or appetite disorders and a need for soft toys [25]. Foreign researchers note that in preschoolers, sleep and eating disorders, anxiety, emotional and behavioural changes [27] can be aggravated by inadequate adult responses explained by insufficient discussion of separation and death issues [28]. They are able to show aggression in games. They may also have psychosomatic disorders of the gastrointestinal tract: stomach pain [25]. Most children between the ages of five and nine perceive death as something final for all living things but do not believe that this event will affect them personally. They are able to reassure themselves that they can avoid it thanks to their own ingenuity. Children of this age usually personify death, which can lead to sleep disorders. Having a certain life experience, they are able to freely express their feelings about the fact of loss and experience an increased sense of guilt. They are characterised by the ability to control their own feelings to a certain extent, hide tears for fear of losing self-control or upsetting their parents, and show a caring attitude towards their mother or younger family members. Among psychosomatic disorders, abdominal pain is most often observed [25]. Starting from the age of nine or ten and up to the older adolescence, children are able to overcome their fear by learning philosophical ideas about life and death, the existential meaning of life. When faced with loss, they have a sense of anxiety and may show regression in childhood fears, to Aesopian behaviour and "magical" thoughts. Psychosomatic disorders are similar to those in younger children. Seriously ill children are internally traumatised, although outwardly they show Independence, show anger and irritability [25]. A. Aleksandrova points out that children of older adolescence have an almost formed concept of understanding death. In general, their behaviour is characterised by denial of the fact of death with an emphasis on adult perception, there is an increase in fear of their own death, manifestations of depression and isolation, as well as risky behaviour and unconscious searches for physical reassurance, which can also have a sexual character [25].

So, based on the results of the analysis, we can distinguish the following main features of the perception of death by seriously ill children in accordance with cognitive, emotional and behavioural aspects (Table 1).

Table 1. Features of perception of death by seriously ill children

\begin{tabular}{c|c|c|c} 
Child's age & Cognitive aspect & Emotional aspect & Behavioral aspect \\
Infants & $\begin{array}{c}\text { They don't understand } \\
\text { what death is }\end{array}$ & $\begin{array}{c}\text { Fear, sadness, anger, } \\
\text { depressed mood }\end{array}$ & They feel the emotional state of adults and react to them \\
\hline 6-18 months & $\begin{array}{c}\text { Death is recognised } \\
\text { as a temporary absence } \\
\text { or separation }\end{array}$ & Fear, sadness & $\begin{array}{l}\text { They respond to the mood and emotions of their parents. } \\
\text { They want to be with their parents and need their attention. } \\
\text { They express their demands through crying, showing } \\
\text { aggression to other loved ones. } \\
\text { They need comfort and comfortable conditions of stay }\end{array}$ \\
\hline
\end{tabular}


Table 1, Continued

\begin{tabular}{|c|c|c|c|}
\hline Child's age & Cognitive aspect & Emotional aspect & Behavioral aspect \\
\hline Infants & $\begin{array}{l}\text { They don't understand } \\
\text { what death is }\end{array}$ & $\begin{array}{l}\text { Fear, sadness, anger, } \\
\text { depressed mood }\end{array}$ & They feel the emotional state of adults and react to them \\
\hline $\begin{array}{l}18 \text { months - } \\
5 \mathrm{y} .\end{array}$ & $\begin{array}{l}\text { They are aware of the } \\
\text { fact of transition and } \\
\text { begin to show the ability } \\
\text { to discuss the issue of } \\
\text { separation } \\
\text { and death }\end{array}$ & $\begin{array}{l}\text { Guilt } \\
\text { and various fears, } \\
\text { including fear for } \\
\text { their own health }\end{array}$ & $\begin{array}{l}\text { They show confusion, which is a consequence } \\
\text { of the internal state of their parents. } \\
\text { It is characterised by egocentrism, belief in one's own } \\
\text { "magical" thoughts. There is isolation, demanding of } \\
\text { others, irritability, possible sleep or appetite disorders. } \\
\text { There is a need for soft toys. } \\
\text { With growing up, they begin to consider themselves } \\
\text { strong, but show fear, a sense of weakness and helplessness }\end{array}$ \\
\hline $5-9 \mathrm{y}$ & $\begin{array}{c}\text { They perceive death as } \\
\text { something finite for all } \\
\text { living things, but they } \\
\text { believe that } \\
\text { it will "bypass them". } \\
\text { They tend to personify } \\
\text { death. They are able to } \\
\text { freely express their own } \\
\text { feelings about the fact } \\
\text { of death }\end{array}$ & $\begin{array}{l}\text { They have an } \\
\text { increased sense } \\
\text { of guilt, } \\
\text { fear of losing } \\
\text { self-control }\end{array}$ & $\begin{array}{l}\text { They are able to control their own feelings to a certain } \\
\text { extent, hide emotions. show respect for significant } \\
\text { others }\end{array}$ \\
\hline $9-10 y \cdot-13 y$. & $\begin{array}{l}\text { Knowledge of } \\
\text { philosophical ideas } \\
\text { about life and death }\end{array}$ & Fears, anxiety & $\begin{array}{l}\text { They are able to overcome fear, demonstrate } \\
\text { independence, anger, and irritability }\end{array}$ \\
\hline Teenagers & $\begin{array}{l}\text { They have a well-formed } \\
\text { concept of } \\
\text { understanding death, } \\
\text { show frustration } \\
\text { conditioned upon the } \\
\text { inability to realise } \\
\text { their own goals }\end{array}$ & $\begin{array}{l}\text { Anger, fear of their } \\
\text { own death }\end{array}$ & $\begin{array}{l}\text { Behavior is characterised by denial of the fact of death. } \\
\text { Isolation, depression, and a tendency to risky behavior } \\
\text { are manifested }\end{array}$ \\
\hline
\end{tabular}

\section{Characteristics of ideas about the constancy and safety of life of a seriously ill child}

In this context, it is worth paying attention to the fact that in a child, information about the approach of death can lead to changes in fundamental ideas about the constancy and safety of life. A serious medical condition affects the significance of each minute and understanding its value. Conditioned upon the approach of death, a seriously ill child is able to delve more into his own inner world of experiences and more deeply realise his uniqueness and uniqueness. The proximity of this event helps to express themsevles fully, to get rid of everything superfluous. The child's awareness of his own fear affects his acceptance and direction in a positive direction (self-development, creativity). That is, a meeting with their own experiences and rethinking them and their own life situation, a deeper understanding of themselves - can lead a seriously ill child to spiritual growth and personal development.

In her monograph "Psychology of life crisis", T. Titarenko also focuses on the fact that many people at the end stage of the disease are able to overcome their own suffering and find a meaning that contributes to the transformation of the internal and external world and develops a special interpersonal microclimate. She calls it the paradox of resonance of the inner and higher, past and present [29, p. 319].

Foreign researchers J. Milam, A. Ritt-Olson, and J. Unger note that it is older adolescents who are more likely to indicate positive changes than younger children. In their opinion, late adolescence is optimal for the occurrence of post-traumatic growth [30]. Scientists V. Helgeson, K. Reynolds, $\mathrm{P}$. Tomich point out that the ability to self-analyse is developed in children at the age of eleven [31].

A. Alexandrova in her book "Illness and death. Conversations with a psychologist about stress" describes the life event of a fourteen-year-old girl Marzhana, who had an oncological diagnosis. A seriously ill child, having constant intense pain and rapid fatigue, realised his own cherished dream. She, with the help of friends and volunteers, organised a personal photo exhibition of her own amazing photographs, mainly in the portrait genre, and recorded a video appeal to everyone who could hear her. The girl analysing what happened to her indicates that the experience and knowledge gained exceeded the value of her life as a whole. She advised everyone to make the most of their opportunities 
through love, ethics, and happiness. The teenager emphasised that the disease teaches faith, hope and resilience through pain, despite uncertainty and fears [25].

A. Kholmogorova, A. Sergienko, and A. Gerasimova assign a special role to parents in the post-traumatic growth of seriously ill children [32]. Based on the results of their own experimental research, they state that parents who support the child's initiative and have good emotional contact with him are able to celebrate the positive moments of his life, have self-confidence and show readiness to overcome difficulties. These parents also focus less on the negative aspects of life, avoid self-blame, pessimistic attitudes about the future [32, p. 21-22]. Researchers V. Kotuna, M. Jelinek, M. Blatny, and T. Kepak believe that warm interpersonal relationships have a number of advantages in traumatic experiences and are crucial in helping children who have survived cancer [33]. H. Sharp, V. Willard, S. Barnes point out that it is parental support, reassurance and distraction from the child's health problem that acts as a mechanism that affects the appearance of post-traumatic growth of cancer-stricken adolescents [34]. That is, it can be argued that it is parental support and acceptance of a difficult crisis situation that contribute to their rethinking of complex life experiences and developing new behaviours that serve as the basis and meaning of their own life and are an example for a seriously ill child.

It can be argued that the direct perception of death by a child can affect the appearance of post-traumatic stress disorder or push him to rethink the existential meaning of life. Parental support plays a crucial role in the emergence of the post-traumatic growth of a seriously ill child.

\section{CONCLUSIONS}

So, in the process of theoretical analysis of scientific sources, the specific features of perception of death by a seriously ill child are considered. It is established that children, like adults, go through certain stages of acceptance of death. At the same time, they have certain differences in the process of passing these stages compared to adults. Direct communication of the diagnosis to a child causes a similar reaction to the message of death. In a child, in particular, a seriously ill person, the development of an idea of death occurs along with his growth, depends on his life experience and age characteristics, and as the level of culture of the inner circle and their religious confessions affect him. It is established that the direct feelings of adults and their fear of the death of a child are often transmitted to young patients and affect their perception of this fact. Differences in the views of scientists regarding the age-related features of the perception of death by a seriously ill child are revealed. In general, researchers point to the determinism of the stages of development of perception of death by a child. The key features of the perception of death by seriously ill children in accordance with cognitive, emotional and behavioural aspects are highlighted. It is determined that prolonged illness causes traumatic emotional experiences and depletion of the body's adaptive reserves in the child. Direct mental development of children affects the depth and duration of their experiences, and their immersion in their own feelings of grief and grief. A debilitating disease can cause a child to develop symptoms of post-traumatic stress disorder. Also, information about the approach of death can cause changes in the child's own fundamental ideas about the constancy and safety of life.

The prospect of further research is to develop methodological recommendations for parents and doctors on the specifics of supporting a seriously ill child, considering his "picture of the world", personality to improve life and saturate it with meaning.

\section{REFERENCES}

[1] Emery, J. (2017). Truly useful guide to pediatric palliative care for doctors and nurses around the world. Moscow: Prospect.

[2] Klipinina, N.V, Khain, A.E, \& Kudryavitskiy, A.R (2014). Doctor-family-patient communication in pediatric oncology/hematology: Diagnosis and treatment disclosure. Counseling Psychology and Psychotherapy, 1, 127-155.

[3] Parsons, S. K., Saiki-Craighill, S., Mayer, D., Sullivan, A., Jeruss, S., Terrin, N., Tighiouart, H., Nakagawa, K., Iwata, Y., Hara, J., Graie, H., \& Block, S. (2007). Telling children and adolescents about their cancer diagnosis: Cross-cultural comparison between pediatric oncologist in the US and Japan. Psycho-Oncology. 16(1), 60-68.

[4] Katolyk, H., \& Stulkiwska, M. (2020). Children's perception of death: Age and pain aspects. Social \& Legal Studios, 2(8), 210-217.

[5] Speece, M.W., \& Brent, S.B. (1992). The acquisition of a mature understanding of three components of the concept of death. Death Studies, 16(3), 211-229.

[6] Kane, B. (1979). Children's concepts of death. The Journal of Genetic Psychology, 134(1), 141-153.

[7] Binnebezel, J., \& Katolyk, H. (Eds.). (2018). Palliative and hospice care. Lviv: Ukrainian Catholic University.

[8] Gesell, A., Ilg, F.L., \& Ames, L.B. (1977). The child from five to ten. New York: Harper \& Row.

[9] Orbach, I., Gross, Y., Glaubman, H., \& Berman, D. (1985). Children's perception of death in humans and animals as a function of age, anxiety and cognitive ability. Journal of Child Psychology and Psychiatry, 26(3), 453-463.

[10] Zlyvkov, V.L., \& Lukomska, S.O. (2017). The list of Hippocrates. Nizhyn: PP Lysenko M.M.

[11] Penkov, A.Yu., \& Riha, O.O. (2017). What to talk to the child. Kharkiv: Vodnyi Spektr GMP. 
[12] Legare, C.H., Evans, E.M., Rosengren, K.S., \& Harris, P.L. (2012). The coexistence of natural and supernatural explanations across cultures and development. Child Development, 83(3), 779-793.

[13] Slaughter, V. (2005). Young children's understanding of death. Australian Psychologist, 40(3), 179-186.

[14] Oaklander, V. (2007). Windows to our children. Moscow: Nezavisimaya firma "Klass".

[15] Kubler-Ross, E. (2001). About death and dying. Moscow-Kyiv: Sofia.

[16] Bayer, O.O. (2010). Life crises of the individual. Dnipro: Oles Honchar Dnipro National University.

[17] A child's concept of death. Stanford children's health. (n.d.). Retrieved from https://www.stanfordchildrens.org/en/ topic/default?id=a-childs-concept-of-death-90-P03044.

[18] Panagiotaki, G., Nobes, G., Ashraf, A., \& Aubby, H. (2015). British and Pakistani children's understanding of death: Cultural and developmental influences. British Journal of Developmental Psychology, 33(1), 31-44.

[19] Vasilets, O., \& Obuhov, Ya. (1998). If a child does not want to live. Narodnoe Obrazovanie, 9-10, 15-18.

[20] Tkach, R.M (2008). Fairytale therapy of children's problems. Saint Petersburg: Rech.

[21] Gutiérrez, I.T., Menendez, D., Jiang, M.J., Hernandez, I.G., Miller, P., \& Rosengren, K.S. (2020). Embracing death: Mexican parent and child perspectives on death. Child Development, 91(2), 491-511.

[22] Tomchuk, M.I., \& Yatsiuk, M.V. (2016). Socio-psychological support for children experiencing parental loss. Vinnytsia: PHEE "Vinnytsia Academy of Continuing Education".

[23] Nykonenko, Yu.P. (Ed.). (2016). Clinical psychology. Kyiv: KNT.

[24] Schonfeld, D.J., \& Demaria, T. (2016). Supporting the grieving child and family. Pediatrics, 138(3), article number e20162147.

[25] Aleksandrova, O.V. (2015). Disease and death. Talking to a psychologist about stress. Saint Petersburg: Mikhail Fursov Printing House.

[26] Yalom, I.D. (1980). Existential psychotherapy (1 $1^{\text {st }}$ ed.). New York: Basic Books.

[27] Bugge, K.E., Darbyshire, P., Rokholt, E.G., Haugstvedt, K.T.S., \& Helseth, S. (2014). Young children's grief: Parents' understanding and coping. Death Studies, 38(1-5), 36-43.

[28] Renaud, S-J., Engarhos, P., Schleifer, M., \& Talwar, V. (2015). Children's earliest experiences with death: Circumstances, conversations, explanations, and parental satisfaction. Infant and Child Development, 24(2), 157-174.

[29] Titarenko, T.M. (1998). Psychology of life crisis. Kyiv: Agropromvydav Ukrainy.

[30] Milam, J.E., Ritt-Olson, A., \& Unger, J.B. (2004). Posttraumatic growth among adolescents. Journal of Adolescent Research, 19(2), 192-204. doi: 10.1177/0743558403258273.

[31] Helgeson, V., Reynolds, K., \& Tomich, P. (2006). A meta-analytic review of benefit finding and growth. Journal of Consulting and Clinical Psychology, 74(5), 797-816. doi: 10.1037/0022-006X.74.5.797.

[32] Kholmogorova, A.B., Sergienko, A.I., \& Gerasimova, A.A. (2020). Setting to support the child's subjective position and post-traumatic growth in parents of children with disabilities. Cultural-Historical Psychology, 16(1), 13-24. doi: 10.17759/chp.202016010.

[33] Koutná, V., Jelínek, M., Blatný, M., \& Kepák, T. (2017). Predictors of posttraumatic stress and posttraumatic growth in childhood cancer survivors. Cancers (Basel), 9(3), 26. doi: 10.3390/cancers9030026.

[34] Howard Sharp K.M., Willard, V.W., Barnes, S., Tillery, R., Long A., Phipps S. (2016). Emotion socialization in the context of childhood cancer: Perceptions of parental support promotes posttraumatic growth. Journal of Pediatric Psychology, 42(1), 95-103. doi: 10.1093/jpepsy/jsw062. 


\author{
Людмила Володимирівна П’янківська ${ }^{1}$, Тетяна Борисівна Кодлубовська ${ }^{2}$ \\ ${ }^{1}$ Державний науково-дослідний інститут МВС України \\ 01011, пров. Є. Гуцала, 4А, м. Київ, Україна \\ ${ }^{2}$ Національний університет охорони здоров’я імені П.Л. Шупика \\ 04112, вул. Дорогожицька, 9, м. Київ, Україна
}

\title{
Особливості сприйняття смерті тяжкохворою дитиною
}

Анотація. Актуальність дослідження зумовлюється недостатнім висвітленням питання переживання й усвідомлення смерті тяжкохворими дітьми. Досліджувана проблематика загалом стосується базових екзистенційних питань особистості дитини та ії батьків й потребує певних напрацювань щодо особливостей повідомлення дитині невтішної новини, ведення з нею розмови про смерть і безпосереднього сприйняття цього факту, а також певної побудови сімейних стосунків. Метою статті є дослідження особливостей сприйняття смерті тяжкохворою дитиною. Автори задля досягнення мети опираються на методологію системного підходу та використовують комплекс наукових методів, серед яких аналіз, синтез, взаємозв'язок, порівняння, а також систематизація і узагальнення. Установлено, що сприйняття смерті тяжкохворою дитиною залежить від вікових особливостей, термінальної стадії розвитку захворювання, рівня інтелектуального розвитку, наявного власного досвіду. Проаналізовано наукові джерела та продемонстровано вікові особливості сприйняття смерті тяжкохворою дитиною. Виокремлено психологічні складові щодо усвідомлення й розуміння факту смерті дитиною на термінальній стадії розвитку захворювання з урахуванням іiі віку. Охарактеризовано особливості ставлення до смерті тяжкохворих дітей на когнітивному, емоційному та поведінковому рівнях. Продемонстровано, що інформація про наближення смерті здатна призводити до змін фундаментальних уявлень про постійність і безпеку життя дитини. Перспективи подальших досліджень зосереджені на розробці методичних рекомендацій батькам і лікарям щодо підтримки тяжкохворої дитини з урахуванням іiі «картини світу», індивідуальності задля насичення позитивними моментами життя

Ключові слова: фази сприйняття смерті, вікові особливості, емоційний стан, поведінковий і когнітивний аспект, страх, тривожність, посттравматичний стресовий розлад 